Article

\title{
Appraisals of Childbirth Experience in Hungary
}

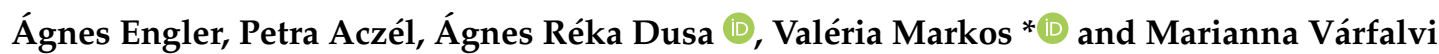

Maria Kopp Institute for Demography and Families, 1016 Budapest, Hungary; engler.agnes@koppmariaintezet.hu (Á.E.); aczel.petra@koppmariaintezet.hu (P.A.); dusa.agnes@koppmariaintezet.hu (Á.R.D.); varfalvi.marianna@koppmariaintezet.hu (M.V.)

* Correspondence: markos.valeria@koppmariaintezet.hu

check for updates

Citation: Engler, Ágnes, Petra Aczél, Ágnes Réka Dusa, Valéria Markos, and Marianna Várfalvi. 2021. Appraisals of Childbirth Experience in Hungary. Social Sciences 10: 302. https://doi.org/10.3390/socsci 10080302

Academic Editor: Sandra Walklate

Received: 19 July 2021

Accepted: 8 August 2021

Published: 11 August 2021

Publisher's Note: MDPI stays neutral with regard to jurisdictional claims in published maps and institutional affiliations.

Copyright: (c) 2021 by the authors. Licensee MDPI, Basel, Switzerland. This article is an open access article distributed under the terms and conditions of the Creative Commons Attribution (CC BY) license (https:// creativecommons.org/licenses/by/ $4.0 /)$.

\begin{abstract}
The main focus of our research is to identify the factors that impact childbirth experience positively and negatively, with special attention to the case of caesarean sections. Drawing on a telephone survey conducted over four years between 2021 and 2018, we use data on 2000 Hungarian mothers and assessed a total of 4266 births. According to the regression analysis, there is a significant association between childbirth experience and settlement type, marital status, financial situation and factors measuring social support, as well as between high-risk pregnancy and informal patient payments. Significant results relating to caesarean sections indicate that the proportion of this mode of birth is higher among women who are older, completed a higher level of education and who live in settlements of a larger type. Based on regression analysis, we can conclude that the likelihood of opting for a caesarean section increases with the mother having a degree or diploma, giving birth with support from an obstetrician of her own choice, experiencing high-risk pregnancy or being older.
\end{abstract}

Keywords: childbirth; marital satisfaction; caesarean section

\section{Introduction}

The conditions of childbirth and their immediate (or short-term) implications for families constitute an important theme that should be examined in its own right. Childbirth is a life-changing event, a life-long experience for the family as a whole. The long-term impact of childbirth experience is crucial from three perspectives. First, we can point to the importance of developing and maintaining mother-child and father-child relations, since bonding (its pattern, nature and strength) has a decisive role from the first moment of life (Moore et al. 2012). The second perspective is that of the young (children, siblings and young indirect relatives) within the family who witness the arrival of the new family member or have first-hand knowledge of the childbirth narrative. Considering the propensity of these young people to have their own children, the kind of emotional content and specific experiences that imbue family stories are by no means insignificant (Issokson 1990; Jouhki et al. 2016). The third perspective transcends the boundaries of the nuclear family and is projected to society as a whole: demographic trends are not independent of individual experiences. The mother and the father who, on the whole, had a positive experience of their child's birth may find it easier to decide about having their next child (Nilsson et al. 2010; Shorey et al. 2018).

Although we focus on childbirth experience in studying these questions, the periods of pregnancy and newborn care should not be forgotten either. These stages also delineate the theoretical units of this article. The antenatal period plays a decisive role in preparation for childbirth. During these months, the mother gradually develops increasingly frequent and deeper relationships with physicians, nurses and midwives as well as with her infant (Fleming et al. 2011; Lothian 2006; Karlström et al. 2015). This network of (professional) contacts and the surrounding institutional environment can do much to ensure that the mother will experience the forthcoming event under safe conditions (Lavender et al. 
1999; Henriksen et al. 2017). For example, the obstetrician's professional competence and personal relationship with the mother, the building and technical apparatus of the obstetrics department, and the quality of examinations conducted during the nine months of pregnancy (to list but a few) may all induce pleasant expectations and strong confidence or, in worse cases, doubts and distrust in expectant mothers.

Of course, the equation is not so simple, since within this interplay between a multiplicity of factors the strong may offset the weaker ones, changes may occur over time, and the mother and her surroundings are preparing continuously, with shifting expectations, for the arrival of the child. However, the "aggregate effect" is an essential component of the journey towards delivery.

The main focus of our studied topic, the process and experience of childbirth, is an individual issue. Surveys of family sociology usually seek an answer to the question of which factors influence the experience of childbirth. These factors may be linked to human or financial resources, but they also include experiences of pregnancy. Thus, research on childbirth experience gauges the circumstances of a specific moment. Surprisingly, the woman experiencing childbirth and her family receive less attention, while individual attributes (described by demographic indicators) and socioeconomic background can also be explanatory variables in the development of childbirth experience. This study aims to present findings from research that took account of these background variables and drew attention to important relationships.

Finally, the short postpartum period is similarly crucial. The behaviour of the family member who is present during the life event of childbirth (or another person asked to do so) or, by contrast, the absence of a relative, may also influence how labour is experienced and remembered. Such memories and impacts strongly affect the feelings and thoughts of the people experiencing this event, primarily those of the mother, during the hours and days following childbirth. Without questioning the significance of longer-term effects, this study focuses on the early postnatal period.

Our objectives are to investigate the sociocultural background, social support, a supportive hospital environment and the informal payment effects to the childbirth experience, and we reveal the factors that influence the negative birth experiences. The study's other aims are to investigate the circumstances of caesarean sections among at-risk mothers and mothers with different sociocultural backgrounds.

\section{Theoretical Background}

\subsection{The Hungarian Context of Pregnancy and the Postnatal Period}

An expectant woman, as well as the life of the foetus from the moment of conception, enjoy special legal protection and support, as articulated in The Fundamental Law of Hungary (25 April 2011) and related statutes and decrees. Besides declaring these rights, their enforcement should also be ensured by both the health care system and the expectant parents themselves. Free prenatal and intranatal care provided by the state as well as the expertise and skills of various professionals are especially important because they contribute significantly to the mother's sense of safety. The Health Act determines the mother's right to choose the person who may accompany her during labour and birth. A government decree regulates the free choice of institution and doctor as well as the criteria and professional rules of home birth. The decree on prenatal care prescribes that, in addition to the screening tests carried out by physicians and health visitors, professional consultation and communication of a range of self-help and supportive knowledge and methods should be provided within the framework of preparation/education for pregnancy, birth and breastfeeding. The scientific and methodological foundations for this were laid by a Hungarian workgroup introducing and inspiring a family-centred approach and care in obstetrics, which had been adopted by several other fields, institutions and research workshops (Tiba and Paál 1987; Tiba and Várfalvi 1989). (See the list of relevant Hungarian laws after the bibliography). 
From the mid-1980s onwards, a family-centred approach gained momentum and a movement emerged which became increasingly open to preparing expectant couples for pregnancy, birth, breastfeeding and, in intranatal care, the demands of the mothers and childbearing couples, the physiological and psychological needs of the foetus, stressfree, gentle ways of giving birth and being born, and support for early bonding and breastfeeding on demand (Tiba and Várfalvi 1989). In 1992, WHO launched the "BabyFriendly Hospital Initiative", an approach and movement that had been adopted early in Hungary, first by the University of Debrecen Gynaecology and Obstetrics Clinical Centre.

In 2018, the Hungarian government took a decision on family-friendly measures. The aim is to implement the family-friendly values, the family- and child-friendly approach, as widely as possible, and to create family-friendly measures and regulatory environments for this purpose. The Government agrees with the development concept of domestic maternity care that satisfies the needs of families, increases the birth of a new family, a positive childbirth experience, and the comfort of the childbirth period, and that Hungarian obstetric institutions operate in as family-friendly a way as possible.

Irrespective of how childbirth occurs, it is an essential question whether childbirth experience has an impact on the propensity to have a child in the future. In a related study, Kisdi (2016) concludes that the appraisal of birth does not affect future childbearing plans. This issue depends least of all on the actual process of delivery, with future plans being affected rather by the experience of pregnancy and puerperium. According to a survey of childbearing plans in countries of the European Union (Testa 2006), $40 \%$ of respondents said that they had had fewer children than they wished to have when they were 20 years old; (Hungary came sixth; the lowest proportion of those who felt that they could fulfil their plans were found in Denmark, while two-thirds of respondents said that they could achieve the desired number of children in Bulgaria, taking the last position). Among reasons for differences in planned and realized number of children, health issues and problems with the partner figure most frequently, while no reference to childbirth experience has been found.

The reason for childbearing postponement and (often parallelly) failure to have another child/more children is frequently associated with improvement in levels of education. Young people stay at school for increasingly longer periods, which delays events in their personal lives. Nevertheless, the intended number of children is the highest by far among those with tertiary-level education; in fact, it exceeds conspicuously the expected reproduction level even during their academic years. Data from a survey with a sample of 1500 show that the average number of planned children is 2.5 among university students (Engler 2018). Studies conducted by Kopp (2010) revealed that the opening of the scissors for the numbers of desired versus actually delivered children is the widest among those with tertiary-level education, particularly women. While three decades ago an increase in education was normally associated with a decrease in the number of children, today women with secondary and tertiary level education show similar fertility, which is in turn lower (approximately 1.6) than fertility among women who completed a lower level of education (2.4). Women who stay at school for longer periods in order to obtain a degree or diploma usually catch up for the number of children during the shorter fertile period after graduation, which women with lower education began at a younger age (Kapitány and Spéder 2015). Moreover, it can also be noted that child-raising students are by no means at a disadvantage - on the contrary, their academic activity and attainment exceeds that of their childless peers (Engler 2017).

\subsection{The Experience, Conditions and Impacts of Childbirth}

The majority of related literature highlights that the evaluation of childbirth experience is influenced by (professional) human factors and material conditions as well as events that occur during this process and the socio-cultural status (see, for example, Hildingsson et al. 2011; Malacrida and Boulton 2012; Sallay et al. 2015; Kisdi 2016; Larkin et al. 2017). 
Human factors include the physician's person and expertise, the midwife's work, and the presence of supportive family members or other companions. Kisdi (2016) examined approximately 70 birth experiences through in-depth interviews. She concluded that the physician's person, rather than strictly his/her activities and involvement, is crucial with respect to the mother's sense of safety. Another decisive factor was found to be the presence of the mother's partner. Most respondents asked their partners to be present, and even when an operation was necessary, it proved to be helpful that the father could witness the event through a glass panel. The partner's presence and support also manifest hormonally, since it can activate the central oxytocin system, facilitating labour (Varga 2015). The role of supportive relationships (father, parents, siblings, and friends) is highlighted in the study by Aune et al. (2015). According to their results, a stable network makes women emotionally strong, so they are better able to cope with stress, and so the experience of childbirth becomes positive. Hildingsson et al. (2011) associate a father's positive birth experience and, later, the strength of ties between father and child with the degree and quality of engagement experienced during the childbirth process. Some research called attention to the psychological aspect of preparation, supporting efforts to provide psychophysical preparation for expectant women, which has, in addition to obstetrical advantages, positive physiological, psychological and emotional outcomes in the delivery room (Tiba et al. 1985; Tiba and Miklósi 1987; Duncan and Bardacke 2010; Henriksen et al. 2017; Abbass-Dick et al. 2020; Damashek et al. 2020).

The primary aspects of the labour and birth process are duration, degree of pain, methods of pain relief and surgical techniques and the mode of birth (natural or caesarean section), while the involvement of the childbearing woman and her partner in the process is also essential. Involvement during childbirth is also a crucial issue in evaluating this process. Women who were continuously informed by their doctors or midwives, and who were asked about their opinions and consent at each stage, tend to have more favourable memories of the labour and birth process (Lavender et al. 1999; Henriksen et al. 2017). Those who were present not as patients but as partners did not feel as if they were in the usual hospital hierarchy. This positive attitude becomes clear already in the early stage of pregnancy: in the course of examinations, consultations and preparation expectant mothers are treated as equals. If, for instance, we focus on the question of artificially increasing the oxytocin level (OT infusion), we can see that methods of its application and giving information on its effects receive little attention. Yet, "maternal OT infusion during labour may reach the brain of the fetus, exposure to OT in the postnatal period gives rise to lifelong effects. These effects include antistress-like effects, such as the lowering of blood pressure and corticosterone levels, an increased pain threshold and weight gain. The effects are sometimes not apparent until adulthood" (Jonas et al. 2007, p. 61; see also Varga 2009, p. 468).

Nurses and midwives also have an important role in childbirth experiences. Often women are grateful for their husbands' and families' help, but they preferred a nurse's care. Sometimes, it is felt that doctors and nurses concentrate on technology rather than their care (Fleming et al. 2011). A midwife can help women with preparing for birth, providing information, increasing understanding, and keeping up communication. As a result, women may develop confidence in the process of labour and birth and in their own ability to give birth (Lothian 2006). A positive relationship between mother and midwife contributes to the positive experiences (Karlström et al. 2015).

Kitzinger (2006) notes that hospital protocols and the authoritarian system of this "total" institution also force caregivers working in obstetrics to conform to a well-established hierarchy of relations, which hinders the mother's otherwise special treatment. In addition to this mechanized, technocratic system, unpredictability and the lack of information also increases the distance between the actors of this inherently natural process (Soltész et al. 2015). However, childbirth satisfaction is to result from having a sense of control, having expectations met, feeling empowered, confident and supported (Farahat et al. 2015). Partly because of this, in Central and Eastern Europe the rate of giving informal payment 
to doctors is high, as in Hungary. According to studies, paying women hope that their obstetrician will be more acceptable and respectful to them and they will get higher quality care. The most important paying factor was the promise of the chosen doctors' presence at delivery, even if the presence of the chosen obstetrician leads to unnecessary interventions (Baji et al. 2017).

Some studies show a strong correlation between antenatal care, childbirth experience and social background. Inequality is appearing among women requiring antenatal care (Pandey et al. 2004). Often the young, rural, lower-income mothers and less educated women may not benefit from antenatal care services or may drop out due to barriers and low-quality services (Oyinlola et al. 2018). According to the surveys conducted by Varga et al. (2011), decisions on family formation, pregnancy and childbirth conditions are influenced by age, educational background, health, financial situation and social support. Studying young women's views of childbirth, Sallay et al. (2015) found diverse attitudes to giving birth, with influencing background factors such as subjective well-being, religiosity and the respondent's own experience of being born. While some research shows that socio-economic status has only a slight significant effect on satisfaction (Mocumbi et al. 2019), other research suggests that women are more satisfied with maternal care living in the countryside, where they did not give informal payment and where the educational level is highest (Mehata et al. 2017; Tocchioni et al. 2018).

Most obstetrics divisions aim to ensure that the newborn has bodily contact with the mother as soon as possible, for example by putting the infant on the mother's abdomen right after delivery so that she can caress her child. However, not all institutions follow this practice, or certain conditions and necessary medical treatments do not allow the mother or newborn to experience it. Nowadays, the imminent need for skin-to-skin contact (imprinting) between mother and child is not considered a condition for early attachment, since it is not supported by scientific evidence that the absence of such contact has a harmful effect on the mother-child relationship (Gervai 1997). The fulfilment of this objective is also supported by preparing expectant mothers through the transfer of knowledge, methods and practical techniques (Várfalvi 1999). Childbirth as well as skin-to-skin contact immediately after birth and the initiation of suckling within the first, "golden hour" of life are crucial events (Moore et al. 2012). Subsequently, when the mother and the newborn are accommodated together, exclusive breastfeeding facilitated within the framework of the rooming-in service promotes the infant's adaptation and resilience, and successful suckling establishes the basis for his/her healthy physical and mental development. For the mother too, breastfeeding is a natural process, hormonally supported by her body, but numerous affective and cognitive factors may influence the ability and effectiveness of breastfeeding. Nevertheless, the role of early attachment is undebatable; its long-term impact on the child can be detected in the partnerships and parental role he or she would have in adulthood (see, for example, Diehl et al. 1998; Feeney and Noller 1990; Fraley 2002; Roelofs et al. 2006; Pace and Zappulla 2011; Szalai 2014).

Delivery by caesarean often prevents the mother and the newborn from staying actively together. However, this is not the only reason for C-sections being under scrutiny. While WHO defines the optimum rate of caesarean sections as $10-15 \%$, average rates for both Europe as a whole and Hungary are considerably higher than this figure (Gibbons et al. 2010), and very different around the world (Sepehri and Guliani 2017; Harrison et al. 2017; Boatin et al. 2018). In Hungary, there is a significant increase in the proportion of C-sections: as much as $41 \%$ were registered for 2018 , compared to $20 \%$ of births in 2000 . In the same period, the rate of planned interventions grew from $6 \%$ to $13 \%$, while the proportion of operative interventions ordered during labour increased from $14 \%$ to $26 \%$. The increase in caesarean rates can be explained, among other factors, by an increase in maternal age, previous caesarean births, the obstetrician's growing professional experience and certain periods of time, such as workdays or December (Gyarmati et al. 2009). According to other research, the great amount of increase in caesarean section frequency cannot be explained 
only by classical obstetric risk factors nor the higher maternal age, but is presumably related to changes in provider and midwife attitudes (Cavallaro et al. 2016; Póka et al. 2020).

Data from a ten-year longitudinal study in Hungary (Gyarmati 2010) show that an approximately four-year increase in the average age of childbearing women has raised the rate of operative intervention by $5 \%$. This can be interpreted with the result that increased maternal age may entail prolonged labour and inefficient uterine contractions. The same study suggests that the relationship between obstetricians' professional experience and the number of caesarean births may be explained with the composition of the group who can make autonomous decisions on the mode of delivery (more elderly doctors) and accumulated knowledge (more adverse experience with wrong decisions and pregnancy outcomes), and that more experienced obstetricians probably undertake to conduct more complicated deliveries. Based on his research findings, Gyarmati concludes that a further increase in CS rates is predictable. Due to a change in approach (the newborn and the mother can leave hospital only when both of them are healthy), doctors have to meet strong societal demands, which is also reflected in the increasing number of malpractice lawsuits. Preference for CS is also justified by the fact that advanced surgical methods, modern technical devices and experience gained makes this intervention increasingly safe, and the chance of CS causing complications has decreased (or certain problems may manifest much later). Thus, when considered with a view on safe outcomes and when its potential late harmful effects on the mother are ignored, caesarean section seems to be the mode of birth with fewer risks.

Not only caution on the part of doctors, but also childbearing women's fear, may support preference for this solution. Review studies such as Sallay et al. (2015) or Karlström et al. (2011) clearly show that women prefer C-sections because of their fear of birth. Women who prefer to give birth with C-section, most likely to try to avoid damage to the body, are also likely to choose the caesarean section because of their ability to plan the time of birth, while some of them believe CS is better, safer and healthier for the mother (Stoll et al. 2017).

We can raise the question of how these mothers evaluate their caesarean births afterwards (irrespective of whether it was elective, planned, or the outcome of a process that started as a natural birth). In some narratives of childbirth experience, respondents consider caesarean section the same process of "giving birth" as natural delivery and report that it does not impact their birth memories or appraisals negatively or positively (Kisdi 2016). However, Malacrida and Boulton (2012) found in their survey that women who had gone through unplanned C-sections were less likely to experience the rite of passage to motherhood. Furthermore, Carquillat et al. (2016) found that women who gave birth by caesarean section (especially emergency CS) reported more negative feelings about their first moments with the newborn, felt less safe, had a more negative relationship with staff, and felt worse in the month after giving birth. The results of Karlström et al. (2011) suggest that women who give birth with a chosen caesarean section are not more satisfied with the birth experience compared to women who give birth vaginally, so a caesarean section is not a guarantee of a positive birth experience.

Some studies point out that informal payment strengthens the social selection, and this effect is reflected in the number of planned caesarean sections (Veroszta and Boros 2020). Mothers give birth in public hospitals, and often an out of pocket paid private doctor at birth undercuts health care access and contributes to increasing social inequalities (Schaaf and Topp 2019; Veroszta and Boros 2020). The chances of a caesarean section are also higher among elderly women, those in a better financial position, those with higher education and those living in urban environments, or if complications have developed during pregnancy (Amjad et al. 2018; Rydahl et al. 2019).

Yet, how birth is perceived is not based solely on personal experience. Widespread or latent narratives of childbirth (giving birth and being born), as well as dominant patterns of representation in the media greatly influence this impression prior to gaining actual experience. These cultural perceptions in turn may also be decisive in how the woman understands the birth process and what kind of decisions she makes about her own 
delivery. Prior knowledge on birth may derive from several sources such as (a) experience of a previous delivery, (b) interactions with doctors and health visitors during antenatal care, (c) birth narratives of family members, relatives and friends, (d) often dramatic representations of childbirth experience in the media or (e) social media communities. It is also clear that media as the most effective agents of socialization have a great impact on how the woman experiences childbirth (Morris and McInerney 2010; Prot et al. 2015; Luce et al. 2016). Representations of birth in the media as dramatic, painful and dangerous, its portrayal as an extraordinary life event, the underrepresentation of obstetric nurses, health visitors and midwives and the fact that media content is less likely to reflect uncomplicated birthing may influence expectations of childbirth and promote the medicalization of this natural phenomenon; eventually, it can affect both the process and experience of childbirth.

Generally, data drawn from literature show that childbirth experience is positively impacted by better sociocultural backgrounds and social (family) support, while it is negatively influenced by high-risk pregnancy and caesarean. This study is based on the assumption that a caesarean section has a negative effect on the childbirth experience, and that groups with more favourable sociocultural backgrounds tend to have a higher rate of caesarean births.

Our hypotheses are the following:

Hypothesis 1. We hypothesize that the childbirth experience is positively influenced by better sociocultural background (Varga et al. 2011; Sallay et al. 2015; Oyinlola et al. 2018), social support (Duncan and Bardacke 2010; Hildingsson et al. 2011; Aune et al. 2015; Kisdi 2016; Henriksen et al. 2017; Abbass-Dick et al. 2020; Damashek et al. 2020) a supportive hospital environment (free choice of doctor and midwife, hospital equipment), (Lavender et al. 1999; Kitzinger 2006; Lothian 2006; Fleming et al. 2011; Farahat et al. 2015; Karlström et al. 2015; Henriksen et al. 2017) and informal payment (Baji et al. 2017).

Hypothesis 2. Mothers at risk are more likely to have a negative birth experience (high risk pregnancy, low birth weight, mother not taking vitamins during pregnancy) and the caesarean section also has a negative impact on childbirth experience (Gyarmati et al. 2009; Gyarmati 2010; Karlström et al. 2011; Malacrida and Boulton 2012; Carquillat et al. 2016; Póka et al. 2020).

Hypothesis 3. The proportion of caesarean sections is higher among at-risk mothers (high riskpregnancies, low birth weight, mother not taking vitamins during pregnancy, high maternal age) and among groups with better sociocultural backgrounds (Gyarmati et al. 2009; Gyarmati 2010; Carquillat et al. 2016; Póka et al. 2020).

\section{Method}

The dataset will be labelled the Childbirth Experience 2019 Database and it is owned by the Mária Kopp Institute for Demography and Families. In the framework of a survey study, 2000 mothers were interviewed. Since Hungarian marketing communication company PromoBox Ltd. has been distributing gift boxes among new mothers for years, beneficiaries were asked and agreed to participate in our research upon receiving their BabyBox. Interviews were based on the number of children and territorial distribution. Data were collected by telephone, from 500 respondents in the years 2012, 2014, 2016 and 2018, respectively. The participation was voluntary and anonymous. Thus, a total of 2000 mothers completed our questionnaire over the four years. Each year, we followed the data collection quotas shown in Table 1. 
Table 1. Distributions by number of children and territorial unit.

\begin{tabular}{lcccc}
\hline & Eastern Hungary & Central Hungary & Western Hungary & Total $(N)$ \\
\hline 1 child & 66 & 67 & 67 & 200 \\
2 children & 66 & 67 & 67 & 200 \\
3 or more children & 33 & 34 & 33 & 100 \\
Total $(N)$ & 165 & 168 & 167 & 500 \\
\hline Source: childbirth experience 2019 database, Mária Kopp Institute for Demography and Families (KINCS).
\end{tabular}

During the compilation of demographic data relating to mothers, responses given by 2000 women were analysed, while analytical data for births and children were drawn from 4266 cases. The research methodology included univariate and multivariate techniques for calculating normal distributions and conducting cross-tabulations, variance and regression analyses.

Our study started from the examination of mothers' sociocultural characteristics (age, education, residence, marital status and financial situation). For marital status, it is important to note that the category of widows has been omitted from interpretation due to the low number of cases included in our sample. The financial situation was measured by a subjective index, by asking mothers to choose from the following categories: "I have no financial worries"; "I can manage well on a budget"; "My income is just enough to cope"; "I have financial problems every month"; "I have to live on a shoestring".

Conditions of childbirth were measured by nine variables (see Table 2) on a five-point Likert scale, where 1 denoted "strongly dissatisfied" and 5 stood for "strongly satisfied". The index is self-improved; the items of the index are based on the literature and midwives" experiences. However, an aggregate variable was also created for examining childbirth experience in which only eight variables were eventually included. The index of childbirth experience did not include pregnancy-related experience, since it spans a longer period preceding the conditions of childbirth. The mean of this index is 29.6 points (with a minimum of 8 points and a maximum of 35 points). As the value of Crombach alpha is 0.737, the index can be considered reliable. We used SPSS v25 (IBM SPSS Statistics for Windows, Version 25.0. Armonk, NY, USA: IBM Corp.) for data analysing.

Table 2. Summary of questions measuring satisfaction, based on means for degree of satisfaction, in descending order.

\begin{tabular}{cc}
\hline Variables Measuring Childbirth Satisfaction (Five-Point Scale) & Means \\
\hline Satisfaction with the obstetric nurse & 4.61 \\
Satisfaction with the obstetrician & 4.55 \\
Quality of antenatal care and preparation for childbirth & 4.53 \\
Overall experience of the perinatal period & 4.38 \\
Satisfaction with hospital staff & 4.30 \\
Satisfaction with the hospital's obstetrics equipment and resources & 4.16 \\
Evaluation of delivery conditions & 4.12 \\
Evaluation of pregnancy & 3.92 \\
Evaluation of initial postpartum days & 3.61 \\
\hline
\end{tabular}

Source: childbirth experience 2019 database, KINCS.

\section{Results}

\subsection{Demographic Characteristics}

Table 3 shows the sociocultural characteristics of mothers participating in our survey. Based on these data, it can be concluded that their average age at the interview was 35.7 years. When arranged in cohorts, it becomes visible that most of them (32.2\%) belong to the age group $35-39$, with $25.4 \%$ being $30-34$ years old and $23.5 \%$ aged $40-44$ at the survey. Members of the youngest cohort, aged 19-24, were represented by $3.4 \%$ and those aged $25-29$ by $10.9 \%$ of respondents, respectively. The oldest mothers, above 45 years of age, consisted of $4.7 \%$ of the total sample. 
Table 3. Demographic characteristics of the sample.

\begin{tabular}{|c|c|c|}
\hline Sample $(N=2000)$ & $N$ & $\%$ \\
\hline Age years & 1995 & 1000 \\
\hline $19-24$ & 67 & 3.4 \\
\hline $25-29$ & 218 & 10.9 \\
\hline $30-34$ & 507 & 25.4 \\
\hline $35-39$ & 642 & 32.2 \\
\hline $40-44$ & 468 & 23.5 \\
\hline $45+$ & 93 & 4.6 \\
\hline Highest level of education completed & 2000 & 100 \\
\hline Primary school (8 years) or lower & 119 & 5.9 \\
\hline Secondary technical or vocational & 274 & 13.7 \\
\hline Secondary general with matura & 698 & 34.9 \\
\hline College (diploma), university (degree) & 909 & 45.5 \\
\hline Permanent residence & 1990 & 100 \\
\hline Budapest & 341 & 17.1 \\
\hline County seat & 389 & 19.6 \\
\hline Other town & 675 & 33.9 \\
\hline Village & 585 & 29.4 \\
\hline Marital status & 2000 & 100 \\
\hline Married & 1367 & 68.3 \\
\hline Living with partner & 458 & 22.9 \\
\hline Single & 102 & 5.1 \\
\hline Divorced & 70 & 3.5 \\
\hline Widowed & 3 & 0.2 \\
\hline Financial situation & 2000 & 100 \\
\hline Have no financial worries & 554 & 27.7 \\
\hline Can manage well on a budget & 1062 & 53.1 \\
\hline Have incomes just enough to cope & 305 & 15.3 \\
\hline Have financial problems every month & 60 & 3 \\
\hline Living in material deprivation & 19 & 0.9 \\
\hline
\end{tabular}

Source: childbirth experience 2019 database, KINCS.

As to the highest level of education among mothers, it is shown that nearly half of respondents had a degree or diploma, 34.9\% completed secondary-level education, $13.7 \%$ vocational and $5.9 \%$ eight years of primary school or lower-level education. Breakdown by settlement type allows us to conclude that $17.1 \%$ lived in the capital, one-fifth in county seats, one-third in towns and $29.3 \%$ in villages. As to marital status, a vast majority of mothers were married, $22.9 \%$ lived with a partner, $5.1 \%$ were single, $3.5 \%$ were divorced and three respondents $(0.2 \%$ of the total sample) were widowed. By financial situation, $27.7 \%$ of mothers described their circumstances as having no financial worries, while half of the respondents felt that they could manage well on a budget each month. Further, 15.2\% of the worse-off said that their incomes were just enough to cope, $3 \%$ indicated that they had to face financial problems every month and $0.9 \%$ of the total sample reported that they lived in material deprivation.

\subsection{Results for Childbirth Conditions}

The study of birth conditions has revealed that mothers were the most satisfied with obstetric nurses and obstetricians and less satisfied with other hospital staff, but still ranked them with a mean of 4.3 points on a five-point scale (Table 2). Data also show that respondents were more satisfied with hospital employees than the conditions experienced at the obstetrics department. They considered pregnancy and the days immediately following delivery the worst periods.

The sociocultural background was measured by the mother's settlement type of residence, education, marital status and subjective financial situation (Table 4). Relationships between the childbirth experience index and these background variables had been explored through analysis of variance. A strong significant association was found between settlement type and childbirth experience. Findings plot a U-shaped curve for satisfaction, that 
is, mothers living in villages and the capital are more satisfied, while those living in towns and county seats are less satisfied, compared with the mean for the total sample.

Table 4. Aggregate index for questions of childbirth satisfaction: results of variance analyses of residence, education, marital status and financial situation $(N=4266)$.

\begin{tabular}{|c|c|c|}
\hline Sample $(N=4266)$ & $N$ & Means \\
\hline \multicolumn{3}{|c|}{ Settlement type of respondent's residence $(0.001)$} \\
\hline Budapest & 689 & 29.8 \\
\hline County seat & 814 & 29.2 \\
\hline Other town & 1439 & 29.5 \\
\hline Village & 1322 & 30.0 \\
\hline \multicolumn{3}{|c|}{ Marital status (0.004) } \\
\hline Married & 3070 & 29.8 \\
\hline Living with partner & 871 & 29.5 \\
\hline Single & 183 & 28.7 \\
\hline Divorced & 136 & 29.0 \\
\hline Widowed & 6 & 32.1 \\
\hline \multicolumn{3}{|c|}{ Financial situation (0.000) } \\
\hline Have no financial worries & 1142 & 30.2 \\
\hline Can manage well on a budget & 2280 & 29.7 \\
\hline Have incomes just enough to cope & 651 & 29.0 \\
\hline Have financial problems every month & 149 & 28.5 \\
\hline Living in material deprivation & 44 & 26.8 \\
\hline \multicolumn{3}{|c|}{ Had an obstetrician or obstetrical nurse of their own choice $(0.000)$} \\
\hline Chose their own & 2933 & 29.8 \\
\hline Did not choose & 1330 & 29.2 \\
\hline \multicolumn{3}{|c|}{ The father or another relative could be present during delivery $(0.000)$} \\
\hline Yes & 3545 & 29.9 \\
\hline No & 716 & 28.2 \\
\hline \multicolumn{3}{|c|}{ The father was present in the delivery room when his child was born $(0.000)$} \\
\hline Yes & 2559 & 30.1 \\
\hline No & 1702 & 29.0 \\
\hline \multicolumn{3}{|c|}{ High-risk pregnancy $(0.000)$} \\
\hline Yes & 1582 & 37.5 \\
\hline No & 2682 & 38.5 \\
\hline \multicolumn{3}{|c|}{$\begin{array}{c}\text { Caesarean section } \\
(0.000)\end{array}$} \\
\hline Yes & 1473 & 36.9 \\
\hline No & 2793 & 38.7 \\
\hline
\end{tabular}

Source: childbirth experience 2019 database, KINCS.

Variance analysis also allowed us to examine relationships between childbirth experience and the mother's education. Results show that there is no significant association between these two variables. However, statistical relationship can be discovered between marital status and childbirth experience. According to our data, mothers living in marriage were the most satisfied with their delivery conditions, followed by women living with a partner, then the divorced. Single mothers proved to be the most dissatisfied.

The indicator of subjective financial situation also shows a strong significant association with childbirth experience. Data reflect that the better a mother considered her financial situation, the more positive childbirth experience she had, and the worse a mother considered her financial situation, the more negative opinion she had about her childbirth experience.

In addition to social background variables, the role of social support in relation to childbirth experience was also examined (Table 4). The salience of freedom in choosing a doctor is highlighted by the result that women who relied on an obstetrician or obstetric nurse of their own choice for conducting delivery were significantly more satisfied. Mothers who decided themselves about who their doctors or nurses should be had 29.8 points, while those who did not had 29.2 points on the childbirth experience scale. 
The importance of social and family support was highlighted by two questions, which showed that respondents for whom the father or another relative were allowed to be present at delivery, or the father entered the delivery room during the birth of his child, were significantly more satisfied. Mothers gave a childbirth experience evaluation of 29.9 points in cases when the father or another relative could be present to witness delivery and 28.2 points when they could not be present. Childbirth experience received 30.1 points when the father was present in the delivery room and 29 points when he was not, respectively.

High-risk pregnancy and childbirth experience also show strong significant associations. Mothers who did not face complications during pregnancy had more positive experiences than those who had gone through a high-risk pregnancy. Mothers who gave birth by caesarean section experienced childbirth more negatively. Taking vitamins and informal patient payments did not show significant relationships with antenatal experience.

Table 5 shows the results of a linear regression model of childbirth experiences. Strong significant associations $(p=0,000)$ can be detected between childbirth experience on the one hand and financial situation, father or relative presence, choice of doctor, and caesarean section on the other hand. The correlations are somewhat weaker between birth experience and marital status, high-risk pregnancy, and informal payment ( $p \leq 0.002)$, while the weakest significant effect was the settlement type $(p=0.02)$ The analysis also included the mother's education, father's presence and taking vitamins as explanatory variables, but these had no significant impact.

Table 5. Linear regression model of childbirth experience.

\begin{tabular}{|c|c|c|}
\hline $\begin{array}{c}\text { Variables Included in Linear Regression } \\
\text { Analysis }\end{array}$ & $\begin{array}{l}\text { Standardized Coefficients } \\
\text { (Beta) }\end{array}$ & Significance \\
\hline $\begin{array}{l}\text { Settlement type }(1=\text { capital, county seat, } \\
\qquad 0=\text { town, village })\end{array}$ & -0.036 & 0.020 \\
\hline $\begin{array}{c}\text { Education }(1=\text { degree } / \text { diploma, } 0=\text { other } \\
\text { qualification })\end{array}$ & -0.014 & 0.416 \\
\hline $\begin{array}{c}\text { Marital status }(1=\text { living with partner, } \\
0=\text { not living with partner })\end{array}$ & -0.009 & 0.583 \\
\hline $\begin{array}{c}\text { Marital status }(1=\text { other, } \\
0=\text { married } / \text { living with partner })\end{array}$ & -0.049 & 0.002 \\
\hline $\begin{array}{l}\text { Perceived financial situation }(1=\text { no } \\
\text { worries } 0=\text { worse-off })\end{array}$ & 0.077 & 0.000 \\
\hline $\begin{array}{l}\text { Father's presence }(1=\text { present at birth, } \\
0=\text { absent })\end{array}$ & 0.029 & 0.125 \\
\hline $\begin{array}{l}\text { Father or relative }(1=\text { could be present, } \\
\qquad 0=\text { could not be present })\end{array}$ & 0.073 & 0.000 \\
\hline $\begin{array}{c}\text { Choice of doctor }(1=\text { own doctor, } 0=\text { other } \\
\text { doctor })\end{array}$ & 0.131 & 0.000 \\
\hline High-risk pregnancy $(1=$ yes, $0=$ no $)$ & -0.053 & 0.001 \\
\hline $\begin{array}{c}\text { Taking vitamins }(1=\text { took vitamins, } 0=\text { did } \\
\text { not take vitamins })\end{array}$ & -0.005 & 0.728 \\
\hline $\begin{array}{l}\text { Informal payments }(1=\text { made payments, } \\
0=\text { did not pay })\end{array}$ & -0.058 & 0.002 \\
\hline $\begin{array}{c}\text { Caesarean section }(1=C S, 0=\text { Natural } \\
\text { birth })\end{array}$ & -0.123 & 0.000 \\
\hline \multicolumn{3}{|c|}{$\mathrm{R}^{2} 0.061$} \\
\hline
\end{tabular}

Source: childbirth experience 2019 database, KINCS. Significant results are signed by bold.

\subsection{Results for Caesarean Section}

For $34.5 \%$ of mothers participating in our survey, a caesarean section had been applied as the mode of birth at least once (i.e., for 1473 infants from among a total of 4266). Of these caesareans, $47 \%$ were planned, while for $53 \%$ of respondents a decision was made to do a caesarean during delivery. The results of variance analysis show that a strong significant association $(p=0.000)$ can be found between caesarean section and childbirth experience; 
women who had a natural birth experienced it more positively (30.2) than mothers who had a baby by caesarean (28.5).

Table 6 shows the relationship between mode of birth and maternal age, education and residence settlement type. The mode of birth was associated with the mother's age $(p=0.000)$. Thus, with an increase in maternal age at birth, the proportion of caesarean births grew significantly. Mothers aged 30-34 had the highest rate of caesarean section, while the lowest proportion of caesarean interventions was found among mothers younger than 20 .

Table 6. Relationship between mode of birth and maternal age, education and residence settlement type: cross-tabulation results $(N=4266)$.

\begin{tabular}{|c|c|c|c|c|}
\hline Description & $\begin{array}{l}N \text { (Number of } \\
\text { Births) }\end{array}$ & $\%$ & $\begin{array}{l}N \text { (Number of } \\
\text { Births) }\end{array}$ & $\%$ \\
\hline \multirow{2}{*}{\multicolumn{5}{|c|}{$\begin{array}{c}\text { Delivered by caesarean } \\
\text { Respondent age years by cohort }(p=0.000)\end{array}$}} \\
\hline & & & & \\
\hline Under 18 & 19 & 1.3 & 95 & 3.4 \\
\hline $18-19$ & 20 & 1.4 & 76 & 2.7 \\
\hline $20-24$ & 145 & 9.8 & 408 & 14.7 \\
\hline $25-29$ & 369 & 25.1 & 816 & 29.3 \\
\hline $30-34$ & 520 & 35.3 & 862 & 31 \\
\hline $35-39$ & 319 & 21.7 & 428 & 15.4 \\
\hline Over 40 & 81 & 5.5 & 88 & 3.6 \\
\hline Total & 1473 & 100 & 2784 & 100 \\
\hline \multicolumn{5}{|c|}{ Respondent education $(p=0.000)$} \\
\hline 8-year primary or lower & 64 & 4.3 & 250 & 9 \\
\hline $\begin{array}{l}\text { Secondary technical or } \\
\text { vocational }\end{array}$ & 211 & 14.3 & 385 & 13.8 \\
\hline Secondary general with matura & 502 & 34.1 & 984 & 35.2 \\
\hline Tertiary & 696 & 47.3 & 1174 & 42 \\
\hline Total & 1473 & 100 & 2793 & 100 \\
\hline \multicolumn{5}{|c|}{ Settlement type of respondent residence $(p=0.007)$} \\
\hline Budapest & 231 & 15.7 & 458 & 16.4 \\
\hline County seat & 309 & 21 & 505 & 18.1 \\
\hline Other town & 519 & 35.2 & 920 & 33 \\
\hline Village & 414 & 28.1 & 908 & 32.5 \\
\hline Total & 1473 & 100 & 2791 & 100 \\
\hline
\end{tabular}

Source: childbirth experience 2019 database, KINCS.

Cross-tabulations reveal strong significant associations with the mother's education $(p=0.000)$. Of mothers who had a natural birth, $9 \%$ completed eight years of primary school or a lower level, $13.8 \%$ vocational school, $35.2 \%$ secondary general with a final examination (matura) and $42 \%$ tertiary level. Among mothers who delivered by caesarean, the proportion of women with primary-level education was significantly lower (4.3\%), while the ratio of those with tertiary-level education was significantly higher $(47.3 \%)$, with $14.3 \%$ vocational and $34.1 \%$ secondary general rates within this group.

Again, significant relationship can be discovered between settlement type and mode of birth $(p=0.007)$. Of children delivered naturally, $33 \%$ were born in a town, $32.5 \%$ in a village, $18.1 \%$ in a county seat and $16.4 \%$ in Budapest. By contrast, among children delivered by caesarean, $35.2 \%$ were born in a town, $28.1 \%$ in a village, $21 \%$ in a county seat and $15.7 \%$ in Budapest, respectively.

Based on cross-tabulations, no significant association has been found between the mother's marital status and the self-assessed financial situation of her family.

The likelihood of a caesarean section was also examined by logistic regression. (Caesarean was incorporated into the regression model with the coding $1=$ caesarean birth, $0=$ non-caesarean birth.) Table 7 shows results of regression that no significant effect was found for settlement type, marital status and self-assessed financial situation or for the mother taking vitamins and the child's birth weight. However, C-section likelihood 
increased when the mother had a degree/diploma, chose her own doctor for delivery or went through high-risk pregnancy; moreover, the older the mother was, the more likely it became that she would opt for a caesarean. The strongest significant correlation was between caesarean birth and choice of doctor, high-risk pregnancy, mother's age, father's presence and father or other relative presence $(p=0.000)$, but the education and informal payment have weaker significant effects $(p=0.01)$.

Table 7. Analysis of reasons for a caesarean birth by the logistic regression method.

\begin{tabular}{|c|c|c|}
\hline Variables in the Logistic Regression Model & $\operatorname{Exp}(B)$ & Significance \\
\hline Settlement type ( $1=$ capital, county seat, $0=$ town, village $)$ & 1.124 & 0.163 \\
\hline Education $(1=$ tertiary, $0=$ other $)$ & 1.241 & 0.015 \\
\hline Marital status $(1=$ married, $0=$ not married $)$ & 1.181 & 0.277 \\
\hline $\begin{array}{c}\text { Marital status }(1=\text { living with partner, } 0=\text { not living with } \\
\text { partner })\end{array}$ & 1.145 & 0.420 \\
\hline Self-assessed financial situation $(1=$ no worries, $0=$ worse-off $)$ & 0.896 & 0.223 \\
\hline Father's presence $(1=$ present at birth, $0=$ absent $)$ & 0.288 & 0.000 \\
\hline $\begin{array}{l}\text { Father or other relative }(1=\text { allowed to be present, } 0=\text { not } \\
\text { allowed })\end{array}$ & 0.125 & 0.000 \\
\hline Choice of doctor $(1=$ own doctor, $0=$ not own doctor $)$ & 2.359 & 0.000 \\
\hline High-risk pregnancy $(1=$ yes, $0=$ no $)$ & 2.152 & 0.000 \\
\hline Taking vitamins $(1=$ took vitamins, $0=$ did not take vitamins $)$ & 1.223 & 0.094 \\
\hline Informal payment $(1=$ made payments, $0=$ did not pay $)$ & 1.268 & 0.018 \\
\hline Mother's age & 1.056 & 0.000 \\
\hline Child's birth weight & 1.000 & 0.685 \\
\hline
\end{tabular}

Source: childbirth experience 2019 database, KINCS. Significant results are signed by bold.

\section{Discussion}

In our first hypothesis, we assumed that the childbirth experience is positively influenced by a better sociocultural background (Varga et al. 2011; Sallay et al. 2015; Mehata et al. 2017; Oyinlola et al. 2018; Tocchioni et al. 2018), social support (Duncan and Bardacke 2010; Hildingsson et al. 2011; Aune et al. 2015; Kisdi 2016; Henriksen et al. 2017; Abbass-Dick et al. 2020; Damashek et al. 2020) a supportive hospital environment (free choice of doctor and midwife, hospital equipment) (Lavender et al. 1999; Kitzinger 2006; Lothian 2006; Fleming et al. 2011; Farahat et al. 2015; Karlström et al. 2015; Henriksen et al. 2017), and informal payment (Baji et al. 2017).

Examining the sociocultural background as to settlement type, regression results show that, as projected by the findings from variance analysis, relationship can be discovered between settlement size and childbirth experience. Respondents who lived in smaller settlements reported more positive childbirth experiences than those who lived in bigger settlements (county seats or the capital). Although the results of variance analysis suggested that childbirth experience tends to be more positive among those living in a village or the capital, due to the data reduction entailed by the regression method (the aggregation of variables for village and town as well as county seat and capital) the dominance of the capital proved to be more prominent. As Mehata et al. (2017) highlighted, women living in bigger cities or capitals have more opportunities to choose a doctor, midwife or obstetrics institution according to their own preference.

For marital status, it can be concluded that-in accordance with results from the analysis of variance-divorced and single mothers reported more negative experiences, compared with the married (similar result as Mocumbi et al. 2019). No significant impact was found for those who lived with a partner. Negative experiences can be caused by a lack of social support and a more precarious life situation.

In the case of subjective financial situation calculations by both statistical methods it was revealed that better financial situation has a positive effect on childbirth experience. Thus, mothers who considered their financial situation to be worse reported more negative 
experiences of birth. Those in a better financial position are more likely to afford the extra services and pay a private doctor.

Social support was measured with three variables: whether the child's father or another relative was allowed to be present during delivery; whether the father was actually present during birth; whether the obstetrician conducting the delivery was the childbearing woman's own doctor. Findings from the analysis of variance and regression show significant associations with two variables: the father or another relative was allowed to be present during delivery and the chosen doctor having a positive impact on the childbirth experience. This result, that social support has an outstanding role in the positive appraisal of childbirth experience, is also underpinned by conclusions in Kisdi (2016); Varga (2015); Hildingsson et al. (2011) and Tiba et al. (1985).

According to related literature (Gyarmati et al. 2009; Gyarmati 2010; Karlström et al. 2011; Malacrida and Boulton 2012; Póka et al. 2020), childbirth experience can also be influenced by other factors such as whether the mother was taking vitamins during pregnancy, whether she had a high-risk pregnancy and whether she made informal payments. Results from linear regression and analysis of variance show that high-risk pregnancy has a negative effect on experiences. While regression analysis also revealed the negative impact of informal payments, it has not been confirmed by findings from the analysis of variance. Taking vitamins had no relationship with childbirth experience.

Generally, our first hypothesis that childbirth experience is positively affected by better sociocultural background and social (family) support, while it is negatively influenced by high-risk pregnancy, has been apparently confirmed. "Better sociocultural background" meant a more favourable experience of financial situation and a relationship of marriage, while "social support" referred to whether the father or another relative was allowed to be present at birth, and whether the mother could freely choose her own doctor or obstetric nurse/midwife.

According to our second hypothesis, mothers at risk are more likely to have a negative birth experience (high risk-pregnancy, low birth weight, mother not taking vitamins during pregnancy) and the caesarean section also has a negative impact on childbirth experience (Gyarmati et al. 2009; Gyarmati 2010; Karlström et al. 2011; Carquillat et al. 2016, Carquillat et al. 2016; Póka et al. 2020). Our hypothesis was confirmed, and data show that this relationship exists even if the woman could have chosen a doctor or had better living conditions. According to results, a caesarean section has a negative impact on childbirth experience, and the analysis of variance shows that mothers who had a natural delivery experienced birth more positively. Malacrida and Boulton (2012) point out that women who had gone through unplanned C-sections were less likely to experience the rite of passage to motherhood. The lack of this feeling is probably the reason for a more negative appraisal of childbirth experience.

Results from both regression and the analysis of variance underpinned the assumption that increasing maternal age entails a higher likelihood of caesarean section, a conclusion that also concurs with research findings described by Gyarmati (2010). Both analytical methods have confirmed that caesarean births are more frequent among mothers with higher levels of education (Rydahl et al. 2019). Regression results showed that the likelihood of caesarean intervention was higher when the mother relied on her own doctor in childbirth or she had a high-risk pregnancy (Baji et al. 2017; Amjad et al. 2018; Póka et al. 2020). Therefore, it can be concluded that our third hypothesis has also been confirmed: the proportion of caesarean section is higher among at-risk mothers (high risk-pregnancies, low birth weight, mother not taking vitamins during pregnancy, high maternal age) and among groups with better sociocultural backgrounds (Gyarmati et al. 2009; Gyarmati 2010; Carquillat et al. 2016; Póka et al. 2020). As to maternal age, it is apparent that the older the mother is, the more likely it is that she would opt for delivery by caesarean. Data also showed that the rate of caesarean births is significantly higher among mothers with higher levels of education, and that groups with a better sociocultural background tend to opt 
for caesareans more frequently. In addition, these factors are mutually reinforcing and interrelated (Baji et al. 2017; Schaaf and Topp 2019; Veroszta and Boros 2020).

Some limitations need to be considered when interpreting our results. We first emphasize that the mothers who gave birth during the period participated in the promotion process, however our questionnaire was completed only by those who volunteered for the research. Our research data contain only Hungarian results. In the future, it would be useful to execute our research at the international level for comparability. Furthermore, from 2021 informal payment giving is punished in Hungary, so future results presumably will be modified.

\section{Conclusions}

While the arrival of a child is a gift for society, the community and family alike, it is also a task, responsibility and obligation to protect the newcomer. The quality of giving life is the basis and safeguard of the future. Besides the biological and medical determination of this life event and transformative period, special attention should be paid to psychological processes and their interaction. Affective and cognitive factors may influence the desire to have a child, the success of conception, the acceptance of a new life and adaptation to changes that occur during the months of pregnancy. All of these have an impact on childbirth and bonding with the new-born. They lay the foundations for and strengthen maternal self-esteem and sense of safety, the ability to sustain new life, breastfeeding and parenting, while they also influence the quality of family members' relationships of a new kind.

Relationships between childbearing propensity and socioeconomic status are examined primarily on the basis of education, family structure and financial background. This research started from the assumption that childbirth experience may influence decisions about the further expansion of the family. We have no knowledge of any study that would provide a detailed inquiry into the relationship between childbirth experience and the components of social background, thus we hope that our interdisciplinary research findings allow us to contribute to the discovery of trends with demographic implications.

Author Contributions: Conceptualization, Á.E. and P.A.; methodology, Á.R.D. and V.M.; software, Á.R.D. and V.M.; validation, Á.R.D. and V.M.; formal analysis, Á.E., P.A., Á.R.D., V.M. and M.V.; investigation, Á.R.D. and V.M. resources, Á.E., P.A., M.V.; data curation, M.V.; writing-original draft preparation, Á.E., P.A., Á.R.D., V.M. and M.V.; writing-review and editing. Á.R.D., V.M.; visualization, V.M. and Á.R.D.; supervision, Á.E. and P.A.; project administration, V.M. and Á.R.D.; funding acquisition, V.M. and Á.R.D. All authors have read and agreed to the published version of the manuscript.

Funding: This research received no external funding.

Informed Consent Statement: Not applicable.

Data Availability Statement: Data will be available on request.

Conflicts of Interest: The authors declare no conflict of interest.

\section{References}

\section{Hungarian Sources}

Magyarország Alaptörvénye (25 április 2011) [The Fundamental Law of Hungary (25 April 2011)]. Available online: http://www. kozlonyok.hu/nkonline/mkpdf/hiteles/mk11043.pdf (accessed on 10 August 2020).

Törvény az egészségügyről [Health Act] 1997, CLIV.

Törvény a magzati élet védelméröl [Act on the Protection of Fetal Life] 1992, LXXIX.

Törvény az egészségügyi alapellátásról [Act on Basic Health Care] 2015, CXXIII.

Korm. rendelet az egészségügyi szolgáltatások Egészségbiztositási Alapból történő finanszírozásának részletes szabályairól [Government Decree on the detailed rules for financing health services from the Health Insurance Fund] 43/1999. (III. 3.)

ESzCsM rendelet a területi védőnői ellátásról [Decree of the Ministry of Health, Social Affairs and Family on the care of territorial nurses] 49/2004. (V. 21.) 
Korm. rendelet az intézeten kívüli szülés szakmai szabályairól, feltételeiről és kizáró okairól [Government Decree on the professional rules, conditions and grounds for exclusion of out-of-institution childbirth] 35/2011. (III. 21.)

EMMI-rendelet a várandósgondozásról [Decree of the Ministry of Human Resources on Pregnancy Care] 26/2014. (IV. 8.)

\section{Secondary Sources}

Abbass-Dick, Jennifer, Winnie Sun, Wendy M. Stanyon, Efrosini Papaconstantinou, Valerie D’Paiva, Nilusha Jiwani-Ebrahim, and Cindy-Lee Dennis. 2020. Designing a Mindfulness Resource for Expectant and New Mothers to Promote Maternal Mental Wellness. Parents' Knowledge, Attitudes and Learning Preferences. Journal of Child and Family Studies 29: 105-14. [CrossRef]

Amjad, Aaisha, Uzair Amjad, Rubeena Zakar, Ahmed Usman, Muhammad Zakria Zakar, and Florian Fischer. 2018. Factors associated with caesarean deliveries among child-bearing women in Pakistan: Secondary analysis of data from the Demographic and Health Survey, 2012-13. BMC Pregnancy and Childbirth 18: 113. [CrossRef]

Aune, Ingvild, Helen Marit Torvik, Siv-Tonje Selboe, Ann-Karin Skogås, Janicke Persen, and Unn Dahlberg. 2015. Promoting a normal birth and a positive birth experience-Norwegian women's perspectives. Midwifery 31: 721-27. [CrossRef]

Baji, Petra, Nicholas Rubashkin, Imre Szebik, Kathrin Stoll, and Saraswathi Vedam. 2017. Informal cash payments for birth in Hungary: Are women paying to secure a known provider, respect, or quality of care? Social Science E Medicine 189: 86-95. [CrossRef]

Boatin, Adeline Adwoa, Anne Schlotheuber, Ana Pilar Betran, Ann-Beth Moller, Aluisio J. D. Barros, Ties Boer-ma, Maria Regina Torloni, Cesar G. Victora, and Ahmad Reza Hosseinpoor. 2018. Within country inequalities in caesarean section rates: Observational study of 72 low and middle income countries. BMJ 360: k55. [CrossRef]

Carquillat, Pierre, Michel Boulvain, and Marie-Julia Guittier. 2016. How does delivery method influence factors that contribute to women's childbirth experiences? Midwifery 43: 21-28. [CrossRef]

Cavallaro, Francesca L., Jenny A. Cresswell, and Carine Ronsman. 2016. Obstetricians' Opinions of the Optimal Caesarean Rate: A Global Survey. PLoS ONE 11: e0152779. [CrossRef] [PubMed]

Damashek, Amy, Catherine Kothari, Ariel Berman, Summer Chahin, John R. Lutzker, Kate Guastaferro, Daniel J. Whitaker, Jenelle Shanley, and Shannon Self-Brown. 2020. Engagement in Home Visiting Services during the Transition from Pregnancy to Postpartum: A Prospective Mixed Methods Pilot Study. Journal of Child and Family Studies 29: 11-28. [CrossRef]

Diehl, Manfred, Alexandra B. Elnick, Linda S. Bourbeau, and Gisela Labouvie-Vief. 1998. Adult attachment styles: Their relations to family context and personality. Journal of Personality and Social Psychology 74: 1656-69. [CrossRef] [PubMed]

Duncan, Larissa G., and Nancy Bardacke. 2010. Mindfulness-Based Childbirth and Parenting Edu-cation. Promoting Family Mindfulness during the Perinatal Period. Journal of Child and Family Studies 19: 190-202. [CrossRef] [PubMed]

Engler, Ágnes. 2017. Család mint erőforrás. [Family as a Resource]. Budapest: Gondolat Kiadó.

Engler, Ágnes. 2018. Párkapcsolati elköteleződések és családalapítási szándékok. [Commitments between partners and intentions of family formation]. In Család és karrier. Egyetemi hallgatók jövőtervei. Edited by Ágnes Engler. Debrecen: Felsőoktatási Kutató és Fejlesztő Központ, pp. 12-41.

Farahat, Amal Hussain, Hanan El Sayed Mohamed, Shadia Abd Elkader, and Amina El-Nemer. 2015. Effect of Implementing a Birth Plan on Womens' Childbirth Experiences and Maternal \& Neonatal Outcomes. Journal of Education and Practice 6: 24-31. Available online: https:/ / www.iiste.org/Journals/index.php/JEP/article/view/20039/20397 (accessed on 10 August 2020).

Feeney, Judith A., and Patricia Noller. 1990. Attachment style as a predictor of adult romantic relation-ships. Journal of Personality and Social Psychology 58: 281-91. [CrossRef]

Fleming, Susan E., Denise Smart, and Phillyse Eide. 2011. Grand multiparous women's perceptions of birthing, nursing care, and childbirth technology. The Journal of Perinatal Education 20: 108-17. [CrossRef]

Fraley, R. Chris. 2002. Attachment stability from infancy to adulthood: Meta-analysis and dynamic modeling of de-velopmental mechanisms. Personality and Social Psychology Review 6: 123-51. [CrossRef]

Gervai, Judit. 1997. A korai kötődés jelentősége a gyermek fejlődésében [The significance of early attachment in the child's development]. In A megtermékenyítéstől a társadalomig. Edited by Hidas György. Budapest: Dinasztia Kiadó, pp. 29-39.

Gibbons, Luz, José M. Belizán, Jeremy A. Lauer, Ana P. Betrán, Mario Merialdi, and Fernando Althabe. 2010. The Global Numbers and Costs of Additionally Needed and Unnecessary Caesarean Sections Performed per Year: Overuse as a Barrier to Univer-sal Coverage. World Health Report. Background Paper, No 30. Available online: http://www.who.int/healthsystems/topics/ financing/healthreport/30C-sectioncosts.pdf (accessed on 10 August 2020).

Gyarmati, Béla. 2010. A császármetszés növekvő arányának orvosi és társadalmi okai. PhD-értekezés [Medical and Social Reasons for Increasing CS Rates]. Ph.D. dissertation, Pécsi Tudományegyetem Egészségtudományi Kar Egészség-tudományi Doktori Iskola, Pécs, Hungary.

Gyarmati, Béla, Péter Nagy, and János Tiba. 2009. A császármetszések gyakoriságának változása és néhány feltételezett ok elemzése az Uzsoki utcai kórházban 1999. január 1. és 2009. június 30. között [The causes of increasing CS rate in Uzsoki Central Hospital, Budapest: Findings for the period between 1 January 1999 and 30 June 2009]. Magyar Nőorvosok Lapja 72: $269-72$.

Harrison, Margo S., Omrana Pasha, Sarah Saleem, Sumera Ali, Elwyn Chomba, Waldemar A. Carlo, Ana L. Garces, Nancy F. Krebs, K. Michael Hambidge, Shivaprasad S. Goudar, and et al. 2017. A prospective study of maternal, fetal and neonatal outcomes in the setting of cesarean section in low- and middle-income countries. Acta Obstetricia et Gynecologica Scandnavica 96: 410-20. [CrossRef] [PubMed] 
Henriksen, Lena, Elisabeth Grimsrud, Berit Schei, and Mirjam Lukasse. 2017. Factors related to a negative birth experience-A mixed methods study. Midwifery 51: 33-39. [CrossRef]

Hildingsson, Ingegerd M., Linnea Cederlöf, and Sara Widén. 2011. Fathers' birth experience in relation to midwifery care. Women and Birth 24: 129-36. [CrossRef] [PubMed]

Issokson, Deborah F. 1990. A Phenomenological Study of Children Who Witness the Birth of a Sibling. Massachusetts School of Professional Psychology. ProQuest Dissertations Publishing. Available online: https://www.proquest.com/docview/303936501? pq-origsite $=$ gscholar\&fromopenview $=$ true (accessed on 10 August 2020).

Jonas, Wibke, Ingela Wiklund, Eva Nissen, Anna-Berit Ransjö-Arvidson, and Kerstin Uvnäs-Moberg. 2007. Newborn skin temperature two days postpartum during breastfeeding related to different labour ward practices. Early Human Development 83: 55-62. [CrossRef]

Jouhki, Maija-Riitta, Tarja Suominen, Kirsi Peltonen, and Päivi Åstedt-Kurki. 2016. Participation in siblings'birth at home from children's viewpoint. Midwifery 34: 150-57. [CrossRef] [PubMed]

Kapitány, Balázs, and Zsolt Spéder. 2015. Fertility. In Demographic Portrait of Hungary 2015. Edited by Monostori Judit, Péter Öri and Zsolt Spéder. Budapest: HCSO Hungarian Demographic Research Institute (HDRI), pp. 41-55.

Karlström, Annika, Astrid Nystedt, and Ingegerd Hildingsson. 2015. The meaning of a very positive birth experience: Focus groups discussions with women. BMC Pregnancy Childbirth 15: 251. [CrossRef] [PubMed]

Karlström, Annika, Astrid Nystedt, and Ingegerd Hildingsson. 2011. A comparative study of the experience of childbirth between women who preferred and had a caesarean section and women who preferred and had a vaginal birth. Sexual $\mathcal{E}$ Reproductive Healthcare 2: 93-99. [CrossRef]

Kisdi, Barbara. 2016. Rettenetes—túlélhető—csodálatos. Szülésélmény és szülési hajlandóság [Horrible, bearable, wonderful: Childbirth experience and childbirth propensity]. In Társadalom, kulturális háttér, gazdaság. Edited by Karlovitz János T. Komárno. International Research Institute: pp. 321-31.

Kitzinger, Sheila. 2006. Birth Crisis. Abingdon and New York: Routledge.

Kopp, Mária. 2010. A gender kutatások népegészségügyi és demográfiai jelentősége [Public health and demographic significance of gender research]. Mentálhigiéne és Pszichoszomatika 114: 243-54. [CrossRef]

Larkin, Patricia, Cecily M. Begley, and Declan Devane. 2017. Women's preferences for childbirth experiences in the Republic of Ireland; a mixed methods study. BMC Pregnancy and Childbirth 17: 19. [CrossRef]

Lavender, Tina, Stephen A. Walkinshaw, and Irene Walton. 1999. A prospective study of women's views of factors contributing to a positive birth experience. Midwifery 15: 40-46. [CrossRef]

Lothian, Judith. 2006. Birth plans: The good, the bad, and the future. Journal of Obstetric, Gynecologic, and Neonatal Nursing 35: 295-303. [CrossRef]

Luce, Ann, Marilyn Cash, Vanora Hundley, Helen Cheyne, Edwin van Tejjlingen, and Catherine Angell. 2016. Is it realistic? The Portrayal of Pregnancy and Childbirth in the Media. BMC Pregnancy and Childbirth 16: 40. [CrossRef]

Malacrida, Claudia, and Tiffany Boulton. 2012. Women's perceptions of childbirth "choices": Com-peting discourses of motherhood, sexuality, and selflessness. Gender and Society 5: 748-72. [CrossRef]

Mehata, Suresh, Yuba Raj Paudel, Maureen Dariang, Krishna Kumar Aryal, Susan Paudel, Ranju Mehta, Stuart King, and Sarah Barnett. 2017. Factors determining satisfaction among facility-based maternity clients in Nepal. BMC Pregnancy and Childbirth 17: 319. [CrossRef]

Mocumbi, Sibone, Ulf Högberg, Erik Lampa, Charfudin Sacoor, Anifa Valá, Anna Bergström, Peter von Dadelszen, Khátia Munguambe, Claudia Hanson, and Esperança Sevene. 2019. Mothers' satisfaction with care during facility-based childbirth: A cross-sectional survey in southern Mozambique. BMC Pregnancy Childbirth 19: 303. [CrossRef] [PubMed]

Moore, Elizabeth R., Gene C. Anderson, Nils Bergman, and Therese Dowswell. 2012. Early skin-to-skin contact for mothers and their healthy newborn infants. The Cochrane Database of Systematic Reviews 5: CD003519. [CrossRef]

Morris, Theresa, and Katherine McInerney. 2010. Media Representations of Pregnancy and Childbirth: An analysis of reality television programs in the United States. Birth 37: 134-40. [CrossRef]

Nilsson, Christina, Terese Bondas, and Ingela Lundgren. 2010. Previous Birth Experience in Women with Intense Fear of Childbirth. Journal of Obstetric, Gynecologic E Neonatal Nursing 39: 298-309. [CrossRef]

Oyinlola, Oluwagbemiga A., Adegbenga Sunmola, Aderemi S. Opayemi, and Olusegun A. Mayungbo. 2018. Barriers to Antenatal Care Use, Child Birth Experience and Level of Education on Actual Attendance among Pregnant Women. International Journal of Psychology and Educational Studies 5: 72-80. [CrossRef]

Pace, Ugo, and Carla J. Zappulla. 2011. Problem Behaviors in Adolescence: The Opposite Role Played by Insecure Attachment and Commitment Strength. Journal of Child and Family Studies 20: 854-62. [CrossRef]

Pandey, Arvind, Nandini Roy, D. Sahu, and Rajib Acharya. 2004. Maternal health care services: Observations from Chhatisgarh Jharkhand and Uttaranchal. Economic and Political Weekly 39: 713-20.

Póka, Róbert, Levente Barna, Péter Damjanovich, Zsolt Farkas, Gergő Orosz, Mónika Orosz, Lilla Ördög, Attila Sipos, and Olga Török. 2020. Emelkedő anyai életkor részesedése a császármetszés-frekvencia növekedésében. [Rising maternal age in the increase in cesarean section frequency]. Magyar Nőorvosok Lapja 83: 3-9. 
Prot, Sara, Craig A. Anderson, Douglas A. Gentile, Wayne Warburton, Muniba Saleem, Christopher L. Groves, and Stephanie C. Brown. 2015. Media as Agents of Socialization. In Handbook of Socialization: Theory and Research, 2nd ed. Edited by Joan E. Grusec and Paul David Hastings. New York: Guilford Press, pp. 276-300.

Roelofs, Jeffrey, Cor Meesters, Mijke ter Huurne, Lotte Bamelis, and Peter Muris. 2006. On the Links Between Attachment Style, Parental Rearing Behaviors, and Internalizing and Externalizing Problems in Non-Clinical Children. Journal of Child and Family Studies 15: 331-44. [CrossRef]

Rydahl, Eva, Eugene Declercq, Mette Juhl, and Rikke Damkjær Maimburg. 2019. Cesarean section on a rise-Does advanced maternal age explain the increase? A population register-based study. PLoS ONE 14: e0210655. [CrossRef] [PubMed]

Sallay, Viola, Tamás Martos, and Eszter Hegyi. 2015. Fiatal nők szüléssel kapcsolatos attitûdjei: A Szülés-attitúdök Kérdőív kidolgozása és első eredményei [Young women's attitudes to childbirth: The design and first results of the Childbirth Attitudes Questionnaire]. In Létkérdések a születés körül. Társadalomtudományi vizsgálatok a szülés és születés témakörében. Edited by Kisdi Barbara. Budapest: L'Harmattan, pp. 291-313.

Schaaf, Marta, and Stephanie M. Topp. 2019. A critical interpretive synthesis of informal payments in maternal health care. Health Policy Plan 34: 216-29. [CrossRef] [PubMed]

Sepehri, Ardeshir, and Harminder Guliani. 2017. Regional Gradients in Institutional Cesarean Delivery Rates: Evidence from Five Countries in Asia. Birth 44: 11-20. [CrossRef] [PubMed]

Shorey, Shefaly, Yen Yen Yang, and Emily Ang. 2018. The impact of negative childbirth experience on future reproductive decisions: A quantitative systematic review. Journal of Advanced Nursing 74: 1236-44. [CrossRef]

Soltész, Andrea, Adrienn Rigó, and Nikolett Pápay. 2015. Az együttszülés jelentôsége [The significance of childbirth with a partner]. In Reproduktív egészségpszichológia. Edited by Pápay Nikolett and Adrienn Rigó. Budapest: ELTE Eötvös Kiadó, pp. 353-70.

Stoll, Kathrin H., Yvonne L. Hauck, Soo Downe, Deborah Payne, and Wendy A. Hall. 2017. Preference for cesarean section in young nulligravid women in eight OECD countries and implications for reproductive health education. Reproductive Health 14: 116. [CrossRef] [PubMed]

Szalai, Tamás Dömötör. 2014. A korai kötődési minták és kötődési szorongás jelentősége az egészségben, betegségben, evészavarokban [The significance of early attachment patterns and anxiety in relation to health, illness and eating disorders]. Kapocs 13: 48-57.

Testa, Maria Rita. 2006. Childbearing Preferences and Family Issues in Europe. Special Eurobarometer 253. Wave 65.1. Vienna Yearbook of Population Research 5: 357-79.

Tiba, János, and Miklós Miklósi. 1987. Gondolatok a szülésre felkészítés programjának hazai aktualitásáról [Thoughts on the currency of the childbirth preparation program in Hungary]. Demográfia 4: 431-36.

Tiba, János, and Margit Paál. 1987. A szülésre felkészítő munkacsoport kialakítása és múködési területe [The formation and scope of the childbirth preparation workgroup]. Népegészségügy 68: 131-33.

Tiba, János, and Marianna Várfalvi. 1989. A szülésre felkészítés ajánlott programja [The recommended programme of preparation for childbirth]. Medicus Universalis 3: 25-30.

Tiba, János, Judit Fráter, Ilona Balogh, and Marianna Bognárné Várfalvi. 1985. Pszichoterápiás eljárások kombinálása a szülésre való felkészítésben [Combining psychotherapeutic techniques in preparation for childbirth]. Magyar Pszichológiai Szemle 3: 223-30.

Tocchioni, Valentina, Chiara Seghieri, Gustavo De Santis, and Sabina Nut. 2018. Socio-demographic deter-minants of women's satisfaction with prenatal and delivery care services in Italy. International Journal for Quality in Health Care 30: 594-601. [CrossRef] [PubMed]

Várfalvi, Marianna. 1999. Felkészítés a szoptatásra. A szoptatás támogatása az élet első napjaiban [Preparation for breastfeeding: Support for breastfeeding during the first days of life]. Védőnő 9: 3-5.

Varga, Katalin. 2009. Szexualitás, szülés, kötődés: Az oxitocin pszichoemotív hatásai [Sexuality, childbirth, attachment: The psychoemotive effects of oxytocin]. In Polihistória—köszöntők és tanulmányok Buda Béla 70. születésnapja alkalmából. Edited by Bagdy Emőke, Zsolt Demetrovics and János Pilling. Budapest: Akadémiai Kiadó, pp. 449-76.

Varga, Katalin. 2015. A szülés élménye. Út a "jó minőségư" szüléshez, születéshez [The experience of childbirth: The road to "good quality" delivery and birth]. In Reproduktív egészségpszichológia. Edited by Pápay Nikolett and Adrienn Rigó. Budapest: ELTE Eötvös Kiadó, pp. 67-86.

Varga, Katalin, Andrea Andrek, and Mária Herczog. 2011. A várandósság és a szülés pszichológiai vonat-kozásai és társadalmi beágyazottsága [The psychological aspects and social embeddedness of pregnancy and childbirth]. In A génektól a társadalomig: A koragyermekkori fejlődés szinterei. Edited by Balázs István. Budapest: Nemzeti Család-és Szociálpolitikai Intézet, pp. $230-76$.

Veroszta, Zsuzsa, and Julianna Boros. 2020. The impact of informal payment on Caesarean delivery rates in obstetric care in Hungary. European Journal of Public Health 30. [CrossRef] 